В. М. Мороз, Т. Л. Полеся, Л. В. Фоміна, Ю. Й. Гумінський Вінницький національний медичний університет імені М. І. Пирогова

\title{
ОРГАНІЗАЦІЯ ОСВІТНЬОГО ПРОЦЕСУ У ВІННИЦЬКОМУ НАЦІОНАЛЬНОМУ МЕДИЧНОМУ УНІВЕРСИТЕТІ IМЕНІ М. І. ПИРОГОВА У СВІТЛІ РЕФОРМУВАННЯ ВИЩОЇ МЕДИЧНОЇ ОСВІТИ
}

\author{
V. M. Moroz, T. L. Polesya, L. V. Fomina, Yu. Y. Huminskyi \\ Vinnytsia Pirogov Memorial Medical University
ORGANIZATION OF EDUCATIONAL PROCESS IN VINNYTSIA PIROGOV MEMORIAL MEDICAL UNIVERSITY IN THE LIGHT OF REFORMING HIGHER MEDICAL EDUCATION

\begin{abstract}
На сучасному етапі відбувається інтеграція вищої освіти України у Європейський освітній простір. Затверджені Закон України “Про вищу освіту” та Національна стратегія реформування системи охорони здоров’я в Україні на період 2015-2020 років, що передбачає впровадження сучасних європейських інноваційних технологій у світлі розбудови якості вищої освіти у вищих навчальних закладах, у тому числі й медичних. У Вінницькому національному медичному університеті імені М. І. Пирогова реалізуються сучасні шляхи розбудови забезпечення якості вищої освіти - впроваджено Європейську кредитно-трансферну систему (ЄKТС), опанування навичок роботи з програмою “СКІФ”, створено Навчально-тренінговий центр практичної підготовки лікарів.

Ключові слова: Закон України “Про вищу освіту”; вища освіта; Національна стратегія реформування системи охорони здоров’я України; інноваційні технології вищої освіти; Європейська кредитно-трансферна система (ЄКТС).

On the modern stage there is integration of higher education of Ukraine into European educational space. The ratified Law of Ukraine “About higher education" from 1.07.2014 and National strategy of the reforms of public health of Ukraine for 2015-2020 envisages introduction of modern European innovation technologies in the light of development quality of higher education. In Vinnytsia Pirogov Memorial Medical University the modern ways of development quality of the higher education are realized - the European credittransfer system (ECTS) is implemented, mastering skills for work with the "SKIF" program, Educational center of practical preparation of doctors is established.
\end{abstract}

Key words: Law of Ukraine; higher education; standards of higher education; innovative technologies of higher education; European Credit-Transfer System (ECTS).

Вступ. Угода про асоціацію між Україною та ЄС (глава 22) [2] є одним із керівних документів, у якій наголошується про здійснення реформування медичної галузі відповідно до Європейського плану дій. У світлі наказу Президента України від 12 січня 2015 року № 5/2015 “Про Стратегію сталого розвитку “Україна - 2020” та постанови Кабінету Міністрів України розроблена Національна стратегія реформування системи охорони здоров'я в Україні на період 2015-2020 років, яка є рамковим документом, що формує принципи, пріоритети, задачі та основні подальші кроки реформування української системи охорони здоров'я. Мета реформ - визначення ключових проблем системи охорони здоров'я, потенційних напрямів і шляхів їх розв’язання для формування нової державної політики у сфері охорони здоров'я.

Мета роботи - висвітлення механізмів забезпечення якості вищої освіти на основі досвіду їх реалізації у Вінницькому національному медичному університеті ім. М. І. Пирогова шляхом впровадження Європейської кредитно-трансферної системи (ЄKTС), опанування навичок роботи з програмою “СКІФ”, створення Навчально-тренінгового центру практичної підготовки лікарів.

Основна частина. У світлі євроінтеграції затверджений Закон України “Про вищу освіту” від 01.07.2014 року № 1556-VII [1]. Одним із найважливіших стратегічних завдань вищої освіти України відповідно до прийнятого Закону України

(c) В. М. Мороз, Т. Л. Полеся, Л. В. Фоміна, Ю. Й. Гумінський 
є впровадження сучасних інноваційних технологій навчання, за Європейською кредитно-трансферною системою (ЄКТС) [2, 3], впровадження нових освітніх програм. У ВНМУ ім. М. І. Пирогова запроваджено ЄКТС, метою якої є забезпечення якості вищої освіти та інтеграція національної системи вищої освіти в європейське та світове освітне співтовариство [5]. Реалізація загального плану реформ відбувається у напрямку відповідності європейським стандартам системи до- та післядипломної освіти лікарів. У зв'язку з прогресивними тенденціями глобалізації європейського та світового освітнього простору вища медична школа модернізується в рамках підписання Україною Болонської декларації [6]. На етапі підготовки майбутніх лікарів на рівні міжнародних вимог одним із найважливіших стратегічних завдань вищої освіти України є забезпечення якості медичної вищої освіти, що відповідає міжнародним стандартам [3, 4]. Ідея реформування медичної вищої освіти полягає в адаптації національної системи вищої освіти до європейських стандартів. Метою реформування вищої освіти $є$ створення уніфікованих критеріїв та взаємовизнання дипломів про вищу освіту, сприяння мобільності студентів. Одним з інструментів реалізації цілей євроінтеграції медичної освіти $є$ запровадження в навчальний процес ЄКТС, яка допомагає вузам досягти забезпечення якості медичної освіти у світлі реформування нової системи охорони здоров'я України. У ВНМУ ім. М. І. Пирогова хронологія впровадження стандартів європейської освіти почалась 32005 навчального року шляхом впровадження кредитно-модульної системи навчання (KMC), а з 2009 року запроваджено ЄКТС та її ключові документи. В процесі поетапної імплементації основних положень ЄКТС відбулась поступова коадаптація національних та європейських технологій. Базовими положеннями ЄКTC $є$ запровадження стандартів, рекомендацій та основних інструментів мобільності студентів і викладачів до вузів Європи. ЄКТС створює прозорість навчальних планів, надає допомогу при узгодженні програм навчання мобільним студентам, відображає результати навантаження та навчання, разом з цим забезпечує автономію вузам та відповідальність за якість навчання студента. Перевагами ЄКТС є підвищення мотивації студентів до навчання, впровадження більш гнучкої 7-бальної рейтингової шкали ЄКТС, таким чином Мінфіном та МОН України запроваджена нова система нара- хування стипендій студентам залежно від рейтингу та соціального статусу. Відбулось значне оновлення сайтів університету, впровадження електронної системи первинної документації, журналів обліку успішності студентів, що дає змогу студентам та батькам контролювати досягнення в навчанні. Широко застосовується інноваційне дистанційне навчання, що значно активізує самостійну роботу. Крім позитивних змін, є недоліки: дублювання та перевантаженість деканатів нормативно-звітною документацією, відсутність університетської клініки, недостатнє фінансування вищої медичної освіти, складнощі у матеріально-технічному оснащенні та недостатнє стимулювання праці викладачів. Основні проблеми сьогодення - невідповідність умов навчання вимогам часу, застосування застарілих педагогічних технологій, високий рівень педагогічного навантаження викладача, низький рівень соціального захисту викладачів і студентів. У ВНМУ ім. М. І. Пирогова впроваджені зміни в організації навчального процесу: повернення виробничої лікарської практики студентів 4 та 5 курсів згідно з новою Типовою програмою з проведення виробничої практики, введено уніфіковану шкалу оцінювання успішності студентів для перерахунку традиційних оцінок з 5-бальної системи у європейську бальну шкалу оцінювання, запроваджено єдину залікову книжку для студентів всіх факультетів. 3 2013-2014 навчального року на кафедрах, що викладають дисципліни з предметів ліцензійних тестових іспитів “Крок-1” та “Крок-2”, введені класичні комісійні іспити. 3 метою покращення практичної підготовки студентів та оптимізації методики опанування практичних навичок на базі ВНМУ ім. М. І. Пирогова створений тренінговий навчальний центр для опанування практичних навичок студентами та інтернами з клінічних дисциплін на базі запровадження сучасних тренажерів (у т. ч. комп’ютерних тренажерів у світлі державної програми “СКІФ”), муляжів, фантомів, імітаторів для діагностики, лікування та профілактики різних нозологій, Інтернет-технології з наданням пріоритету загальній практиці - сімейній медицині. Медичний симуляційний центр ВНМУ ім. М. І. Пирогова $€$ унікальним інноваційним багатопрофільним мультидисциплінарним освітнім підрозділом, оснащеним найсучаснішим навчально-методичним, робото-симуляційним та медичним обладнанням, де використовують передові симуляційні освітні технології. Використання технологій симуляції допо- 
магає запобігати лікарським помилкам, а програма перегляду проведеного заняття допоможе провести детальний аналіз ситуації. Викладачі клінічних кафедр приділяють увагу оволодінню студентами практичними навичками та професійними вміннями, особлива увага акцентується на діагностику невідкладних станів та надання медичної допомоги на догоспітальному етапі у дорослих і дітей згідно зі стандартами та протоколами МО3 України. У ВНМУ ім. М. І. Пирогова створений відділ моніторингу якості освіти з метою покращення результатів ліцензійних інтегрованих іспитів “Крок-1”, “Крок2” та “Крок-3”. Мета відділу полягає у постійному контролі якості освіти на всіх етапах навчального процесу, включно і складання попередніх та передекзаменаційних тестувань студентами (інтернами). Головна мета впровадження європейських стандартів ЄKTC - уніфікація та гармонізація національних освітніх систем вищої освіти в країнах Європи з метою підвищення конкурентоспроможності медичних вузів. Крок за кроком поступово удосконалюються шляхи реформування вищої медичної освіти згідно з європейськими стандартами у світлі реалізації Закону України “Про вищу освіту” та Національної стратегії реформування системи охорони здоров’я України. У ВНМУ ім. М. І. Пирогова в 2016-2017 навчальному році згідно з чинним Законом навантаження на викладача складає 600 год (максимальне навчальне навантаження на одну ставку науково-педагогічного працівника не може перевищувати 600 год на навчальний рік). Відповідно до змін педагогічного навантаження на викладачів створені нові робочі програми із скороченням годин на 10-20 \% за рахунок збільшення кількості годин на самостійну роботу студента (СРС) з кожної дисципліни. У світлі міжнародного

\section{Список літератури}

1. Закон України “Про вищу освіту” від 01.07.2014 року № 1556-VII (Редакція станом на 01.07.2014 року). - zakon. Rada.gov.ua.

2. Довідник користувача ЄКТС 2009. Брюссель, 6 лютого 2009 р. - http://www.bologna2009benelux.org.

3. Визначення критеріїв якості в системі безперервного професійного розвитку лікарів та провізорів на основі концепції кредитів / Ю. В. Вороненко, А. М. Сердюк [та ін.] // Медична освіта. - 2007. - № 3. - С. 11-15.

4. Комюніке Конференції міністрів європейських країн, відповідальних за сферу вищої освіти (Лондон, 16-19 травня 2007 року). - К., 2008. - Кн. 4: Основні за- співробітництва ВНМУ ім. М. І. Пирогова бере участь у міжнародних програмах. Протягом наступних 3-х років ВНМУ реалізовуватиме багатонаціональний проект, учасниками якого є 19 університетів 3 різних країн: ПРОЕКТ 530644-TEMPUS-1-2012-1ES-TEMPUS-JPCR HUMAN Security Безпека людини на територіях, забруднених радіоактивними речовинами, фінансуватиметься при підтримці Європейської комісії. Загальна вартість проекту 1410 095,22 євро. Грант-холдером та координатором проекту $є$ University of Cordoba, Іспанія. За прогнозами, попит на вищу освіту через $10-15$ років у світі становитиме близько 230-300 млн осіб, що вимагає надзвичайно конкурентної високоякісної освіти. У ВНМУ ім. М. І. Пирогова розробляється система інтеграції практичної та науково-дослідницької діяльності у світлі європейської академічної тріади діяльності університетів - поєднання педагогічного процесу, наукових досліджень та клінічної практики. Планується налагодити контакти з вузами-партнерами Європи й започаткувати обмін студентами та викладачами для взаємовизнання дипломів про вищу освіту.

Висновки. Таким чином, реалізація реформ вищої медичної освіти уніфікує національну освітню систему України з країнами Європи згідно 3 європейськими стандартами. Реформи у вищих навчальних закладах відбуваються в національних рамках у світлі положень ЄКТС, що дає можливість з боку держави надати кожному студенту шанс здобути освіту світового рівня, стати конкурентоспроможним фахівцем та мати можливість вибору місця праці у будь-якій країні. Кінцевою метою впровадження нових європейських технологій $є$ взаємовизнання результатів навчання та дипломів про вищу освіту.

сади розвитку вищої освіти України. - С. 24-30.

5. Методичні рекомендації щодо запровадження Європейської кредитно-трансферної системи та ії ключових документів у вищих навчальних закладах (лист МОН № 1/9-119 від 26.02.2010 року); наказ МОН України від 16.10.2009 року № 943 “Про запровадження у вищих навчальних закладах України Європейської кредитнотрансферної системи”.

6. Європейська інтеграція вищої освіти України у контексті Болонського процесу. Тематичний випуск часопису “Вища освіта України” № 3, додаток 2. - К., 2015. - 281 c. 


\section{References}

1. Zakon Ukrainy «Pro vyshchu osvitu» vid 01.07.14 №1556-VII (2014). [The Higher Education Act of Ukraine of 01.07.14 №1556-VII] Retrieved from www.zakon.rada. gov.ua [in Ukrainian].

2. Dovidnyk korystuvacha YeKTS 2009 (2009). [ECTS user's reference 2009]. Retrieved from http://www. bologna2009benelux.org [in Ukrainian].

3. Voronenko, Yu.V., \& Serdiuk, A.M. (2007). Vyznachennia kryteriiv yakosti v systemi bezperervnoho profesiinoho rozvytku likariv ta provizoriv na osnovi kontseptsii kredytiv [Establishment of quality criteria in the system of continuous professional development of doctors and pharmacists on the basis of credits]. Medychna osvita Medical education, 3, 11-15 [in Ukrainian].

4. Komiunike Konferentsii ministriv yevropeiskykh krain, vidpovidalnykh za sferu vyshchoi osvity (London 16-19 travnia 2007 roku). Kn.4: Osnovni zasady rozvytku vyshchoi osvity Ukrainy (2008). [Communique of the
European countries ministers, responsible for higher education conference (London, May 16-19, 2007). Part 4: Basics of higher education in Ukraine development]. Kyiv [in Ukrainian].

5. Metodychni rekomendatsii shchodo zaprovadzhennia Yevropeiskoi kredytno-transfernoi systemy ta yii kliuchovykh dokumentiv u vyshchykh navchalnykh zakladakh (lyst MON № 1/9-119 vid 26.02.10 roku) (2010). [Methodological recommendations on European credit-transfer system and its key documents implementation at higher educational institutions (Ministry of Education and Science Letter № 1/9-119 of October 26, 2010)] [in Ukrainian].

6. Yevropeiska intehratsiia vyshchoi osvity Ukrainy u konteksti Bolonskoho protsesu. (2015). [European integration of higher education of Ukraine in the context of Bologna process]. Tematychnyi vypusk chasopysu «Vyshcha osvita Ukrainy» - Special issue of «Higher education of Ukraine», 3 (Appendix 2). Kyiv [in Ukrainian]. 